\title{
PENGARUH MEDIA ROPITRI BERBASIS REALISTIC MATHEMATIC EDUCATION TERHADAP PEMBELAJARAN MATEMATIKA MATERI SIFAT BANGUN DATAR KELAS III SDN KREMBUNG 1 SIDOARJO
}

\author{
Zulfin Rachma Mufidah ${ }^{1}$ Al- Jupri ${ }^{2}$ \\ Pascasarjana, Universitas Pendidikan Indonesia \\ zulfinmufidah@upi.edu
}

\begin{abstract}
The purpose of this reserach is to find out the influence of Ropitri media based on Realistic Mathematics Education toward the mathematics learning about the geometrical material. Learning mathematics is very useful for students because of the mathematical concepts is needed in solving problems related to mathematics in life. Learning would be better if carried out using a realistic approach to fit the student's real-life conditions, based on this statement, researcher had tested ropitri media based on realistic mathematics education toward mathematics learning about geometry material on third grade students of SDN Krembung 1 Sidoarjo. The sample of this research were students in the third grade. The research instruments used were pretest and posttest sheet. Based on the ttest result of the student learning outcomes as the output of a learning process, it isobtained that $t_{\text {count }}$ is $-3,579$ with $t_{\text {table }} d b=51$ at the $5 \%$ significance level is -2.007. It means that $t_{\text {count }}$ less than $t_{\text {table }}$ or $t_{\text {hitung }}(-3.579)<t_{\text {table }}(-2.007)$ and the conclusions of this research is that Ha is acceptable since it has the influence of ropitri media towards the mathematisc learning of third grade students on the geometry materials while $H_{0}$ is rejected.
\end{abstract}

Keywords: Learning Media, Ropitri Media, Realistic Mathematic Education Approach, mathematics learning outcomes

\begin{abstract}
Abstrak
Tujuan penelitian ini adalah untuk mengetahui pengaruh media ropitri berbasis realistic mathematic education terhadap pembelajaran matematika materi sifat bangun datar. Pembelajaran matematika sangat berguna untuk siswa karena konsep matematika sangat dibutuhkan dalam memecahkan masalah yang berhubungan dengan matematika dalam kehidupan. Pembelajaran akan lebih bermakna jika dilaksanakan dengan menggunakan pendekatan realistik agar sesuai dengan kondisi nyata kehidupan siswa. Maka dari itu peneliti mengujicobakan media ropitri yang berbasis realistic mathematic education untuk mengetahui pengaruhnya terhadap pembelajaran matematika materi sifat bangun datar. Subjek dalam penelitian ini adalah siswa kelas III SDN Krembung 1 Sidoarjo. Penelitian yang dilakukan merupakan penelitian eksperimen dengan pendekatan kuantitatif dan desain penelitian Nonequivalent Control Group Design. Instrumen penelitian yang digunakan yaitu lembar pretest dan posttest. Berdasarkan hasil uji t-test dari hasil belajar siswa sebagai output dari sebuah pembelajaran, diperoleh nilai $t_{\text {hitung }}$ sebesar $-3,579$, sedangkan $t_{\text {tabel }}$ $\mathrm{db}=51$ pada taraf signifikansi $5 \%$, diperoleh $\mathrm{t}_{\text {tabel }}$ sebesar 2,007. Hal ini menunjukkan bahwa $\mathrm{t}_{\text {hitung }}$ berada di bawah nilai $t_{\text {tabel }}$ dengan taraf signifikansi 5\%. Sehingga $-t$ hitung $(-3,579)<-t$ tabel $(-2,007)$ dan kesimpulan dari penelitian ini yaitu media Ropitri berpengaruh terhadap pembelajaran matematika materi sifat bangun datar pada siswa kelas III.
\end{abstract}

Kata kunci: Media Pembelajaran, Ropitri, Realistic Mathematic Education, Hasil belajar matematika 


\section{PENDAHULUAN}

Pendidikan merupakan aspek penting dalam kehidupan dan setiap manusia berhak untuk mendapatkannya. Pendidikan juga berfungsi dalam membangun watak manusia dalam menghadapi suatu peradaban bangsa sesuai dengan esensi Permendiknas No. 22 tahun 2006. Oleh karena itu mutu pendidikan harus terus ditingkatkan. Peningkatan mutu pendidikan dapat dilakukan di berbagai lembaga pendidikan formal di antaranya yaitu sekolah dasar. Pendidikan dilaksanakan melalui proses belajar mengajar salah satunya pembelajaran matematika yang membawa peran penting dalam membekali siswa untuk menghadapi fenomena-fenomena kehidupan yang membutuhkan konsep matematika. Matematika adalah suatu ilmu pengetahuan yang menjadi bagian dari kehidupan manusia (Wijaya, 2012). Tanpa disadari bahwa konsep matematika sering digunakan untuk menyelesaikan beberapa masalah dalam kehidupan. Maka sangatlah penting untuk mempelajari matematika.

Fakta yang terjadi pada pendidikan matematika di Indonesia saat ini, adalah matematika sebagai mata pelajaran yang dianggap paling sulit. Siswa menganggap matematika merupakan ilmu berhitung yang sulit sehingga membuatnya merasa malas sebelum mempelajari matematika, terutama siswa sekolah dasar yang sifatnya selalu ingin menghabiskan waktu dengan bermain dan tidak ingin berfikir terlalu rumit. Alasan lain yang mengakibatkan siswa malas belajar matematika adalah kurangnya pengetahuan siswa mengenai manfaat dari materi matematika yang dipelajari bagi kehidupannya. Masalah yang sering terjadi pada siswa yaitu tidak diketahuinya kapan dan dalam kegiatan apakah materi matematika yang dipelajari dapat diterapkan dalam kehidupan.

Sangatlah sulit menerapkan suatu ilmu pengetahuan apabila ilmu pengetahuan tersebut dianggap tidak bermakna. Sukses mempelajari suatu ilmu pengetahuan apabila kita mengetahui esensi utama dari ilmu pengetahuan tersebut. Proses belajar akan terjadi jika pengetahuan yang dipelajari bermakna bagi pembelajar (Freudenthal,1991 dalam Wijaya,2012:3). Suatu ilmu pengetahuan akan bermakna jika pada saat pembelajaran siswa mengetahui keterlibatan materi yang mereka pelajari dengan realita dalam kehidupan, sehingga dalam proses pembelajaran 
perlu dilakukan pembelajaran yang bersifat realistik atau sesuai kondisi nyata kehidupan siswa. Sesuai tujuan pendidikan matematika menurut National Research Council bahwa pendidikan matematika mempunyai tujuan praktis untuk mengembangkan kemampuan siswa menggunakan matematika untuk menyelesaikan masalah yang terkait dengan kehidupan sehari-hari (National Research Council, 1990 dalam Wijaya, 2012:7). Hal sepaham dengan Realistic Mathematic Education oleh Freudenthal yang menyatakan bahwa matematika bukanlah suatu produk jadi yang tiba-tiba dilakukan, sehingga siswa menganggap bahwa ia tidak melakukan "matematika". Pada Realistic Mathematic Education, Freudenthal mengungkapkan bahwa "Mathematic is Human Activity", sehingga pendidikan matematika realistik harus diawali dengan aktivitas manusia yang dapat mendorong siswa untuk berfikir secara matematis ( Fathurrohman, 2015:188)

Terdapat lima karakteristik pada pendidikan matematika realistik, salah satu di antaranya yaitu penggunaan konteks. Konteks digunakan sebagai suatu cara mengawali pembelajaran matematika. Konteks yang realistik tidak harus dengan menggunakan masalah yang ada dalam dunia nyata namun juga bisa dalam bentuk permainan ataupun penggunaan alat peraga (Treffer, 1987 dalam Wijaya, 2012:21). Namun tidak lain bahwa konteks yang realistik ialah dengan menggunakan konsep yang dapat dipikirkan atau dibayangkan oleh siswa. Pendidikan matematika yang menggunakan konteks sebagai pendekatan tidak hanya RME, adapula Mathematic in Context (MIC) di Amerika. MIC dirancang berdasarkan gagagsan oleh National Council of Teachers of Mathematic(NCTM).

Penulis telah melakukan pengamatan di salah satu sekolah dasar yang berada di kabupaten sidoarjo serta membaca beberapa artikel pendidikan terkait tentang penggunaan media pembelajaran sebagai studi referensi. Beberapa sekolah di Indonesia terutama sekolah-sekolah di desa yang kurang menggunakan media pembelajaran, khususnya media pembelajaran yang bersifat realistik dan dapat membantu siswa memahami materi. Pada proses pembelajaran, media berguna sebagai sumber belajar bagi siswa, media dapat mempermudah siswa dalam memahami materi yang dipelajari (Sanjaya, 2012:47). Media juga bisa digunakan sebagai konteks yang dapat digunakan 
sebagai titik awal pembelajaran matematika sesuai pendidikan matematika realistik.

Berdasarkan hal tersebut penulis mempunyai gagasan untuk melakukan eksperimen suatu media pembelajaran yang bernama"Ropitri (roda pintar geometri)" berbasis pendekatan Realistic Mathematic Education. Ropitri merupakan media pembelajaran untuk mengenalkan sifat bangun datar sederhana pada siswa kelas 3 sekolah dasar. Dengan media pembelajaran tersebut penulis ingin mengetahui seberapa besar pengaruh media tersebut terhadap hasil belajar siswa kelas 3 yang mempelajari tentang bangun datar sederhana.

Media pembelajaran Ropitri didesain menggunakan konsep pendekatan realistik, sehingga pada saat pembelajaran matematika guru dapat mengawali pembelajaran dengan permainan yang menerapkan masalah yang ada dalam kehidupan sehari-hari contohnya Permainan Pasar Benda. Pada permainan tersebut guru memberikan berbagi benda bangun datar seperti dan siswa mengidentifikasi sifat dari bangun datar tersebut. Setelah melakukan permainan siswa dapat menggunakan media Ropitri sebagai media croscheck dari pembelajaran yang menggunakan pendekatan dengan konteks permainan Pasar Benda tersebut. Hal itu dilakukan agar siswa mengetahui kesesuaian jawaban mereka sehingga media Ropitri dapat digunakan sebagai sumber belajar.

Adapun harapan dari peneliti mengenai manfaat dari penelitian ini antara lain :

(1) Bagi Guru, melalui penelitian ini guru dapat menggunakan media pembelajaran Ropitri sebagai media pembelajaran yang dapat digunakan pada saat pembelajaran. Guru juga akan lebih mengetahui mengenai pembelajaran dengan menggunakan pendekatan realistik. (2)Bagi Siswa Sekolah Dasar, melalui penelitian ini siswa bisa menggunakan media Ropitri sebagai salah satu sumber belajar mereka pada materi sifat bangun datar sederhana kelas III. Selain itu melalui pendekatan realistik pada pembelajaran siswa dapat berfikir matematis saat melakukan aktifitas matematika dalam kehidupannya. (3)Bagi Sekolah, melalui penelitian ini sekolah mendapatkan referensi tentang media pembelajaran untuk memperbaiki proses pembelajaran dengan memanfaatkan benda-benda sekitar pada saat melakukan pendekatan pembelajaran kepada siswa. (4)Bagi Mahasiswa Pendidikan Guru 
Sekolah Dasar, melalui penelitian ini mahasiswa dapat menggunakannya sebagai referensi pada saat akan melakukan penelitian lebih lanjut terkait dengan penelitian ini. Mahasiswa PGSD juga dapat menggunakan media Ropitri sebagai media pembelajaran matematika materi bangun datar sederhana jika sudah mengajar siswa di sekolah dasar. (5)Bagi Peneliti Pendidikan, penelitian ini dapat digunakan sebagai pembanding ataupun sebagai referensi untuk melakukan selanjutnya yang berhubungan dengan media visual cetak yang berbasis Realistic Mathematic Education (RME).

Tujuan dari penelitian ini adalah untuk mendiskripsikan pengaruh dari media pembelajaran Ropitri yang didesain berbasis pendekatan RME terhadap pembelajaran matematika siswa kelas 3 pada materi sifat bangun datar di SDN Krembung 1 Sidoarjo. Pada penelitian ini, peneliti mengasumsikan bahwa media Ropitri (Roda Pintar Geometri) yang didesain berbasis Realistic Mathematic Education akan berpengaruh pada pembelajaran matematika pada materi sifat bangun datar sederhana, adanya perubahan tersebut dapat dilihat dan disimpulkan dari hasil belajar matematika siswa khususnya materi sifat bangun datar.
Penggunaan media Ropitri dapat digunakan bersamaan dengan permainan matematika sebagai konteks awal yang bertujuan sebagai pendekatan realistik. Suatu Pengetahuan akan bermakna bagi siswa jika proses pembelajarannya menggunakan suatu konteks (CORD, 1999 dalam Wijaya, 2012). Permainan yang mungkin dapat digunakan adalah Pasar Benda. Guru memberikan berbagi benda bangun datar dan siswa mengidentifikasi sifat dari bangun datar tersebut. Setelah melakukan permainan siswa dapat menggunakan media Ropitri sebagai media Croscheck dari pembelajaran yang menggunakan pendekatan dengan konteks permainan Pasar Benda tersebut. Croscheck dilakukan agar siswa mengetahui kesesuaian jawaban mereka.

\section{METODE PENELITIAN}

Penelitian ini merupakan jenis penelitian eksperimen dengan menggunakan pendekatan kuantitatif. Penelitian eksperimen merupakan suatu cara mencari hubungan sebab akibat dari dua faktor yang sengaja ditimbulkan oleh peneliti dengan melakukan penyisihan faktor-faktor pengganggunya (Arikunto, 2010:9). Penelitian eksperimen dilakukan untuk mengetahui akibat suatu perlakuan. 
Sejalan dengan pendapat tersebut, Sugiyono (2014:72) mengemukakan bahwa penelitian eksperimen merupakan metode penelitian yang digunakan untuk mencari pengaruh perlakuan tertentu terhadap yang lain dalam kondisi yang terkendalikan. Sehingga penelitian selalu melibatkan angka dan data karena penelitian kuantitatif lebih banyak menggunakan angka untuk mengumpulkan data, menafsirkan data yang diperoleh dan menampilkan data hasil penelitian.

Rancangan penelitian sebagai langkah yang diikuti oleh peneliti dalam penelitian ini yaitu berupa Quasi Experimental (Eksperimen Semu) dengan menggunakan desain nonequivalent control group design. Kuasi eksperimen dianggap lebih baik dari pada eksperimen sejati terutama pada penelitian pendidikan. Hal tersebut karena penelitian yang melibatkan manusia sebagai subjek umumnya fokus pada kajian dan pengukuran pada aspek perilaku saja. Nonequivalent control group merupakan desain yang hampir sama dengan pre test-post test control group design, namun pada desain ini kelompok eksperimen dan kelompok kontrol tidak dipih secara acak atau random (Sugiyono, 2014:79). Berikut gambaran dari penelitian dengan desain nonequivalent control group yang dilakukan:

\begin{tabular}{|ccc|}
\hline $\mathrm{O}_{1}$ & $\mathrm{x}$ & $\mathrm{O}_{2}$ \\
\hline $\mathrm{O}_{3}$ & & $\mathrm{O}_{4}$ \\
\hline
\end{tabular}

(Sugiyono, 2014:79)

Gambar 1.1 Nonequivalent Control Group Design

\section{Keterangan :}

$\mathrm{O}_{1}=$ Pre test pada kelas eksperimen

$\mathrm{O}_{2}=$ Post test pada kelas eksperimen

$\mathrm{O}_{3}=$ Pre test pada kelas kontrol

$\mathrm{O}_{4}=$ Post test pada kelas kontrol

$\mathrm{X}=$ Perlakuan

Penelitian eksperimen ini dilakukan pada dua kelas yaitu kelas III A sebagai kelas kontrol dan kelas III B sebagai kelas eksperimen. Kedua kelas tersebut sama-sama diberi pre test dan post test, pre test diberikan dengan tujuan untuk mengetahui kemampuan awal siswa. Perlakuan diberikan untuk kelas eksperimen untuk mengetahui hasil eksperimen yang diterapkan oleh peneliti melalui media Ropitri dengan pendekatan Realistic Mathematic Education. Sedangkan untuk kelas kontrol diberikan pembelajaran secara konvensional tanpa perlakuan khusus. Apabila pre test dan perlakuan pada kelas eksperimen telah 
dilakukan, maka peneliti memberikan post test untuk mengukur kemampuan siswa. Melalui post test peneliti dapat menarik sebuah kesimpulan tentang pengaruh dari perlakuan yang diberikan pada kelas eksperimen melalui Ropitri dengan pendekatan Realistic Mathematic Education tersebut.

Penelitian dilaksanakan di SDN Krembung I yang terletak di Desa Krembung Kecamatan Krembung Kabupaten Sidoarjo Jawa Timur. Pada penelitian ini populasi yang digunakan adalah siswa kelas III SDN Krembung yang terdiri dari kelas III A dan kelas III B. Sampel yang digunakan pada penelitian ini adalah sampel jenuh, dimana sampel yang digunakan adalah seluruh anggota populasi. Sesuai dengan kondisi di SDN Krembung I yang memiliki dua rombongan belajar atau dua kelas, maka peneliti menggunakan semua siswa pada setiap kelasnya sebagai sampel. Sedangkan teknik pengambilan sampel sebagai kelas eksperimen dilakukan secara Purposive Sampling, yaitu dengan menentukan sampel yang digunakan dengan pertimbangan tertentu yang dipandang dapat memberikan data secara maksimal (Arikunto, 2010:33). Variabel adalah objek penelitian ataupun segala sesuatu yang menjadi titik perhatian pada suatu penelitian. Dalam penelitian ini variabel yang diukur adalah media Ropitri (Roda Pintar Geometri) dan pembelajaran matematika materi sifat bangun datar.

Pada penelitian yang berjudul pengaruh media Ropitri berbasis Realistic Mathematic Education terhadap pembelajaran matematika materi sifat bangun datar siswa kelas III SDN Krembung I ini peneliti menggunakan instrumen penelitian berupa pre-test dan post-tes yang digunakan untuk mengukur ketercapaian siswa setelah mempelajari materi sifat bangun datar dengan media Ropitri. Peneliti menggunakan instrumen berupa lembar pre-test dan lembar posttest dalam bentuk lembar tes objektif. Sedangkan teknik pengumpulan data yang digunakan dalam penelitian ini yaitu tes hasil belajar sebagai hasil dari pembelajaran matematika. Analisis data pada penelitian ini menggunakan pendekatan kuantitatif, sehingga data yang dihasilkan berupa data kuantitatif yang dihitung menggunakan perhitungan statistik. Instrumen yang digunakan pada saat penelitian harus diuji validitas dan reliabilitas terlebih dahulu untuk mengetahui tingkat kevalidan dan reliabilitas instrumen tersebut. Sebagaimana Arikunto (2010:211) 
mengatakan bahwa instrumen yang baik adalah instrumen yang valid dan reliabel. Selanjutnya uji analisis hasil penelitian dengan menggunakan uji normalitas, homogenitas dan uji t-test untuk menguji hipotesis dalam penelitian ini.

\section{HASIL DAN PEMBAHASAN}

Hasil

Penelitian telah dilakukan dengan menggunakan Nonequivalent Control Group Design sehingga dalam penelitian ini terdapat perbedaan dalam pelaksanaan pembelajaran di masing-masing kelas, yaitu kelas kontrol dan kelas eksperimen.

Pada kelas kontrol pembelajaran dilaksanakan secara konvensional, sedangkan pada kelas eksperimen pembelajaran dilaksanakan dengan menggunakan media Ropitri (Roda Pintar Geometri) berbasis pendekatan Realistic Mathematic Education. Sebelum melaksanakan penelitian peneliti melakukan uji validasi instrumen penelitian untuk mengetahui bahwa media, perangkat, dan lembar tes yang digunakan sebagai teknik pengumpul data pada penelitian agar menjadi valid dan sahih. Berikut validasi yang telah dilakukan: (1) Validasi media pembelajaran, media pembelajaran Ropitri (Roda Pintar Geometri) merupakan media pembelajaran yang berbasis pendekatan Realistic Mathematic Education. Sehingga dalam menggunakan media pembelajaran ini guru harus melakukan pembelajaran yang bersifat realistik sesuai dengan objekobjek realistik yang terdapat pada media. Media Ropitri merupakan media visual cetak berbahan kertas, berbentuk persegi panjang dan lingkaran yang disatukan oleh kancing jepret, kemudian di bukukan lengkap dengan cara pemakaian media. Sehingga menarik minta siswa untuk membaca dan meggunakannya. Validsi media dilakukan pada ahli sebelum media digunakan dalam kegiatan pembelajaran di kelas ekperimen (kelas IIIb). Validasi media bertujuan untuk mengetahui kelayakan dari media sehingga media dapat dikatakan layak dan boleh digunakan pada saat penelitian. Ahli materi dalam validasi media Ropitri berbasis Realistic Mathematic Education adalah Shofan Fiangga, S.Pd, M.Sc dosen Pendidikan Matematika dan Anggota dosen PMRI Universitas Negeri Surabaya. berdasarkan uji validasi yang telah dilakukan oleh ahli, skor validasi yang diperoleh yaitu media Ropitri memiliki tingkat kevalidan sebesar $88,88 \%$. Dari hasil tersebut maka dapat disimpulkan bahwa media Ropitri 
berbasis Realistic Mathematic Education layak digunakan dalam penelitian dan mendapat saran dari ahli untuk menambahkan segitiga sama kaki, sama sisi dan trapesium sama kaki apabila diperlukan. Hal tersebut dapat dicocokkan dengan materi yang ada di kurikulum KTSP. (2) Validasi Perangkat Pembelajaran, uji validasi perangkat pembelajaran dilakukan kepada ahli Pendidikan Matematika Realilistik Indonesia (PMRI) Shofan Fiangga, S.Pd, M.Sc sebagai ahli pembelajaran matematika realistik. Perangkat pembelajaran yang perlu divalidasi untuk penelitian antara lain Silabus, RPP (Rencana Pelaksanaan Pembelajaran), LKS (Lembar Kegiatan Siswa). Berdasar uji validasi yang telah dilakukan oleh ahli, skor validasi yang diperoleh yaitu perangkat pembelajaran yang digunakan penelitian memiliki tingkat kevalidan sebesar $86,11 \%$. Dari hasil tersebut maka dapat disimpulkan bahwa perangkat pembelajaran layak digunakan dalam penelitian tanpa adanya revisi dari pihak ahli. Hanya ada beberapa cacatan untuk memperbaiki kesalahan EYD. . (3)Validasi Instrumen Penelitian, uji validasi instrumen penelitian atau lembar tes dilakukan oleh ahli pembelajaran PMRI Shofan Fiangga, S.Pd, M.Sc. Serta dilakukan juga uji validasi instrumen penelitian (lembar pretest dan posttest) pada siswa kelas III SDN Kedungsumur 1 Sidoarjo.

Berdasarkan uji validasi yang telah dilakukan oleh ahli, skor validasi yang diperoleh yaitu instrumen pretest memiliki tingkat kevalidan sebesar $80,76 \%$ dan instrumen posttest memiliki tingkat kevalidan sebesar $76,92 \%$. Dari hasil tersebut dapat disimpulkan bahwa instrumen penelitian (lembar tes) sudah sesuai dengan materi dan kurikulum, sehingga layak diuji validasi kepada siswa sekolah dasar. Objek validasi instrumen (lembar pre-test dan post-test) pada penelitian ini yaitu siswa SDN Kedungsumur 1 Sidoarjo. Validasi instrumen dilaksanakan pada tangal 16 Maret 2017.

Uji validitas dilakukan pada siswa kelas III karena memiliki karakteristik yang sama dengan siswa kelas III SDN Krembung 1 Sidoarjo. Uji validasi dilakukan pada siswa kelas III SDN Kedungsumur 1 dengan jumlah 15 siswa yang diambil sebagai sampel untuk melakukan uji validitas instrumen atau lembar tes. Setelah divalidasi pada siswa kelas III, maka di dapatkan $r_{\text {hitung }}$ data korelasi skor butir dengan skor soal sebagai berikut: 
Tabel 1.1 Hasil Skor Validasi Lembar Pre-Test

\begin{tabular}{|c|c|c|c|}
\hline \multirow{2}{*}{$\begin{array}{c}\text { Nomor } \\
\text { soal }\end{array}$} & \multirow{2}{*}{$\mathrm{r}_{\text {hitung }}$} & $\mathrm{r}_{\text {tabel }}$ & \multirow{2}{*}{ Keterangan } \\
\hline & & $5 \%$ & \\
\hline 1 & 0,594609 & 0,514 & valid \\
\hline 2 & 0,62346 & 0,514 & valid \\
\hline 3 & 0,550937 & 0,514 & valid \\
\hline 4 & 0,631225 & 0,514 & valid \\
\hline 5 & 0,758639 & 0,514 & valid \\
\hline 6 & 0,751883 & 0,514 & valid \\
\hline 7 & 0,60373 & 0,514 & valid \\
\hline 8 & 0,584 & 0,514 & valid \\
\hline 9 & 0,555169 & 0,514 & valid \\
\hline 10 & 0,550937 & 0,514 & valid \\
\hline 11 & 0,545925 & 0,514 & valid \\
\hline 12 & 0,555169 & 0,514 & valid \\
\hline 13 & 0,904883 & 0,514 & valid \\
\hline 14 & 0,266549 & 0,514 & tidak valid \\
\hline 15 & 0,790468 & 0,514 & valid \\
\hline 16 & 0,285134 & 0,514 & tidak valid \\
\hline 17 & 0,584 & 0,514 & valid \\
\hline 18 & 0,248595 & 0,514 & tidak valid \\
\hline 19 & 0,081372 & 0,514 & tidak valid \\
\hline 20 & 0,686312 & 0,514 & valid \\
\hline 21 & 0,730026 & 0,514 & valid \\
\hline 22 & 0,189867 & 0,514 & tidak valid \\
\hline 23 & 0,904883 & 0,514 & valid \\
\hline 24 & 0,333237 & 0,514 & tidak valid \\
\hline 25 & 0,119421 & 0,514 & tidak valid \\
\hline 26 & 0,161742 & 0,514 & tidak valid \\
\hline 27 & 0,236365 & 0,514 & tidak valid \\
\hline 28 & 0,69592 & 0,514 & valid \\
\hline 29 & 0,441732 & 0,514 & tidak valid \\
\hline 30 & 0,585101 & 0,514 & valid \\
\hline
\end{tabular}

Penghitungan $r_{\text {hitung }}$ pada tabel di atas dengan menggunakan analisis Ms.Excel 2007. Ketentuannya adalah jika sig $>\alpha$ (didapat dari $r_{\text {tabel }}$ dengan melihat jumlah individu dari taraf signifikansi 0,05), maka $\mathrm{H}_{0}$ diterima sedangkan jika sig $<\alpha$, maka $\mathrm{H}_{0}$ ditolak. Jika melihat jumlah siswa atau responden sebanyak 15 anak maka diketahui $r_{\text {tabel }}$ sebesar 0,514 untuk taraf signifikasi 5\%. Dari tabel 4.4 dan tabel 4.5 dapat diketahui bahwa dari 30 soal yang telah dibuat dan telah divalidasi pada siswa kelas III diperoleh 20 soal pre-test dan 22 soal post-test. Soal yang valid dan dapat digunakan sebagai teknik pengumpul data atau instrumen penelitian. Sedangkan untuk soal yang tidak valid digugurkan atau tidak digunakan sebagai soal yang terdapat instrumen penelitian baik pretest ataupun posttest.

Setelah Uji validitas selesai dilakukan, maka selanjutnya dilakukan uji reliabilitas menggunakan data tes yang dihitung dengan rumus Sperman Brown. Hasil $\mathrm{r}_{11}$ yang diperoleh dari perhitungan dibandingkan dengan harga $\mathrm{r}_{\text {teoritik }}$ product moment nilai $\mathrm{r}_{\text {teoritik }}$ diperoleh dengan taraf signifikansi $5 \%$. Jika $\mathrm{r}_{11}>\mathrm{r}_{\text {teoritik maka dapat dikatakan }}$ butir soal tersebut reliabel. Hasil perhitungan reliabilitas instrumen (lembar pre-test dan post-test) yang telah divalidasikan kepada siswa kelas III SDN Kedungsumur 1 adalah sebagai berikut: 
Tabel 1.2

Perhitungan Reliabel Soal Pre-test

\begin{tabular}{|c|c|c|c|c|c|}
\hline Siswa & $\begin{array}{l}\text { Ganjil } \\
(\mathrm{X})\end{array}$ & $\begin{array}{l}\text { Genap } \\
(\mathrm{Y})\end{array}$ & $\mathrm{X}^{2}$ & $\mathrm{Y}^{2}$ & $\mathrm{XY}$ \\
\hline 1 & 10 & 9 & 100 & 81 & 90 \\
\hline 2 & 1 & 3 & 1 & 9 & 3 \\
\hline 3 & 10 & 9 & 100 & 81 & 90 \\
\hline 4 & 10 & 7 & 100 & 49 & 70 \\
\hline 5 & 11 & 8 & 121 & 64 & 88 \\
\hline 6 & 3 & 2 & 9 & 4 & 6 \\
\hline 7 & 2 & 3 & 4 & 9 & 6 \\
\hline 8 & 3 & 3 & 9 & 9 & 9 \\
\hline 9 & 8 & 9 & 64 & 81 & 72 \\
\hline 10 & 8 & 3 & 64 & 9 & 24 \\
\hline 11 & 8 & 8 & 64 & 64 & 64 \\
\hline 12 & 11 & 9 & 121 & 81 & 99 \\
\hline 13 & 7 & 6 & 49 & 36 & 42 \\
\hline 14 & 11 & 9 & 121 & 81 & 99 \\
\hline 15 & 11 & 8 & 121 & 64 & 88 \\
\hline Jumlah & 114 & 96 & 1048 & 722 & 850 \\
\hline
\end{tabular}

Dari data tersebut diperoleh data sebagai berikut:
$\mathrm{N}=15$
$\sum \mathrm{X}^{2}=$
1.048
$\sum \mathrm{X}=114$
$\sum \mathrm{Y}^{2}=772$
$\sum \mathrm{Y}=96$
$\sum X Y=850$

Setelah itu dimasukkan dalam rumus:

$$
\begin{gathered}
r_{x y}=\frac{N\left(\sum X Y\right)-\left(\sum X\right)\left(\sum Y\right)}{\sqrt{\left.\left.\left\{N\left(\sum X^{2}\right)-\left(\sum X\right)^{2}\right)\right\}\left\{N\left(\sum Y^{2}\right)-\left(\sum Y\right)^{2}\right)\right\}}} \\
r_{x y}=\frac{15(850)-(114)(96)}{\sqrt{\left\{15(1.048)-(114)^{2}\right\}\left\{15(772)-(96)^{2}\right\}}} \\
r_{x y}=\frac{12.750-10.944}{\sqrt{\{15.720-12.996\}\{11.580-9.216\}}} \\
r_{x y}=\frac{1.806}{\sqrt{(2.724)(2.364)}} \\
r_{x y}=\frac{1.806}{\sqrt{6.439 .536}} \\
r_{x y}=\frac{1.806}{2.537} \\
r_{x y}=0,711
\end{gathered}
$$

Dari perhitungan di atas diperoleh $r_{x y}=0,711$, setelah memperoleh nilai $r_{x y}$ maka untuk memperoleh indeks reliabilitas soal masih harus menggunakan rumus Spearman-Brown berikut cara perhitungannya:

$\mathrm{r}_{11}=\frac{2 \times \mathrm{r}_{1 / 21 / 2}}{\left(1+\mathrm{r}_{1 / 21 / 2}\right)}$

$r_{11}=\frac{2 \times 0,711}{1+0,711}$

$\mathrm{r}_{11}=\frac{1,422}{1,711}$

$r_{11}=0,831$

Dari perhitungan di atas diperoleh angka reliabilitas $\left(\mathrm{r}_{11}=0,831\right)$, langkah selanjutnya membandingkan dengan tabel $\mathrm{r}$ product moment. Dari tabel diketahui bahwa dengan $\mathrm{N}=15$, harga $\mathrm{r}_{\text {teoritik }}$ untuk taraf signifikansi 5\% adalah 0,514. Dari hasil tersebut diketahui bahwa harga $r_{11}>r_{\text {teoritik yaitu }} 0,831>$ 0,514 maka instrumen tes dinyatakan reliabel.

Setelah instrumen penelitian dinyatakan valid dan reliabel, tahap selanjutnya yaitu peneliti melakukan penelitian. Penelitian dilaksanakan bulan Maret tanggal 22 Maret sampai 25 Maret 2019 di SDN Krembung 1 Sidoarjo. Berikut penjelasan pelaksanaan pembelajaran di masing-masing kelas: (1)Pelaksanaan Pembelajaran di Kelas Kontrol

Pre test dilaksanakan di awal pembelajaran setelah guru melakukan apersepsi dan sebelum siswa menerima materi dari guru. Soal yang diberikan 
kepada siswa sebanyak 20 soal pilihan ganda. Soal pre test di kelas kontrol dikerjakan pada tanggal 22 Maret 2019 pukul 07.10. Pembelajaran dilaksanakan secara konvensional dengan metode ceramah sehingga siswa guru lebih aktif pada saat pembelajaran sedangkan siswa bersifat pasif karena mendengarkan guru ceramah. Pembelajaran secara konvensional dilakukan pada tanggal 22 Maret 2017 mulai pukul 07.30.

Post test diberikan di akhir pembelajaran setelah siswa menerima materi dari guru. Hal ini dilakukan untuk mengetahui tingkat keberhasilan guru dalam pelaksanaan pembelajaran secara konvensional, dapat dilihat melalui hasil belajar siswa. Soal yang diberikan kepada siswa sebanyak 20 soal pilihan ganda. Soal post test dikerjakan pada 22 Maret 2017 pukul 07.50.

Sedangkan pembelajaran menggunakan media Ropitri berbasis Realistic Mathematic Education pada kelas eksperimen berikut pelaksanaannya. Pre test dilaksanakan di awal pembelajaran setelah guru melakukan apersepsi dan sebelum siswa menerima materi dari guru. Soal yang diberikan kepada siswa sebanyak 20 soal pilihan ganda. Soal pre test di kelas eksperimen dikerjakan pada tanggal 23 Maret 2017 pukul 07.10.

Pelaksaan pembelajaran di kelas eksperimen dengan menerapkan media Ropitri berbasis Realistic Mathematic Education sebagai wujud pemberian perlakuan sehingga siswa lebih aktif dalam kegiatan pembelajaran. Realistic mathematic Education merupakan pendekatan pembelajaran yang menggunakan konteks nyata dalam kehidupan sehari-hari siswa sehingga siswa senang dan pembelajaran bermakna bagi siswa. Terdapat kegiatan secara berkelompok dan mandiri. Guru lebih banyak bertindak sebagai fasilitator dan mengawasi jalannya pembelajaran di kelas. Pembelajaran dilakukan pada tanggal 23 Maret 2019 mulai pukul 07.30.

Post test diberikan pada akhir pembelajaran setelah siswa menerima materi dan menggunakan media Ropitri berbasis Realistic Mathematic Education dalam kegiatan pembelajaran. Hal ini dilakukan untuk mengetahui tingkat keberhasilan guru dalam pelaksanaan pembelajaran menggunakan media Ropitri berbasis Realistic Mathematic Education, dapat dilihat melalui hasil belajar siswa. Soal yang diberikan kepada siswa sebanyak 20 soal pilihan ganda. 
Soal post test dikerjakan pada 23 Maret 2019 pukul 07.50.

Penelitian telah dilaksanakan, tahap selanjutnya yaitu mengolah data hasil penelitian berupa hasil pretest dan posttest siswa dari masing-masing kelas. Mengolah data melalui uji normalitas, homogenitas dan kemudian data bisa di uji t-test untuk menjawab hipotesis penelitian.

Uji normalitas, berikut perhitungan normalitas pretest kelas kontrol

a. Nilai Tertinggi $(\mathrm{Xt})=85$

b. Nilai Terendah $(\mathrm{Xr})=50$

c. Range $(\mathrm{R})=(\mathrm{Xt}-\mathrm{Xr})+1$

$$
\begin{aligned}
& =(85-50)+1 \\
& =36
\end{aligned}
$$

d. Jumlah Kelas $(\mathrm{K})=1+3,3 \log \mathrm{N}$

$$
\begin{array}{lr}
=1+3,3 \cdot 1,447 \\
=
\end{array}
$$

(Pembulatan selalu ke atau menjadi 6)

e. Interval (i) $=\mathrm{R}: \mathrm{K}$

$$
\begin{aligned}
& =36: 6 \\
& =6
\end{aligned}
$$

Tabel 1.3

Perhitungan Normalitas Pre-test Kelas Kontrol

\begin{tabular}{|c|c|c|c|c|c|}
\hline No & $\mathbf{X}$ & Fo & fe & $\begin{array}{l}(\boldsymbol{f o} \\
-\boldsymbol{f e})^{\mathbf{2}}\end{array}$ & $\boldsymbol{x}^{\mathbf{2}}$ \\
\hline 1 & 82,5 & 2 & 4,6 & 6,76 & 1,46 \\
\hline 2 & 76,5 & 4 & 4,6 & 0,36 & 0,07 \\
\hline 3 & 70,5 & 8 & 4,6 & 11,56 & 2,51 \\
\hline 4 & 64,5 & 8 & 4,6 & 11,56 & 2,51 \\
\hline
\end{tabular}

\begin{tabular}{|c|c|c|c|c|c|}
\hline 5 & 58,5 & 4 & 4,6 & 0,36 & 0,07 \\
\hline 6 & 52,5 & 2 & 4,6 & 6,76 & 1,46 \\
\hline & 28 & & \multicolumn{3}{|c}{} \\
\hline
\end{tabular}

Berdasarkan hasil perhitungan, ditemukan harga Chi-Square hitung yaitu 8,08 harga tersebut selanjutnya dibandingkan dengan Chi-Square tabel, dengan d. $b=6-1=5$ pada taraf signifikansi $5 \%$, maka harga Chi-Square tabel=11,1. Dapat disimpulkan bahwa harga ChiSquare hitung lebih kecil dari harga ChiSquare tabel $(\mathbf{8 , 0 8}<\mathbf{1 1 , 1})$, maka nilai pretest pada kelas kontrol berdistribusi normal.

Sedangkan untuk normalitas kelas eksperimen, berikut hasil hitung uji normalitas posttest kelas eksperimen:

a. Nilai Tertinggi $(\mathrm{Xt})=100$

b. Nilai Terendah $(\mathrm{Xr})=70$

c. Range $(\mathrm{R})=(\mathrm{Xt}-\mathrm{Xr})+1$

$$
\begin{aligned}
& =(100-70)+1 \\
& =30
\end{aligned}
$$

d. Jumlah Kelas $(\mathrm{K})=1+3,3 \log \mathrm{N}$

$$
\begin{aligned}
& =1+3,3 \cdot 1,397 \\
& =5,61 \text { (Pembulatan }
\end{aligned}
$$

\section{selalu ke atas menjadi 6)}

e. Interval (i) $=\mathrm{R}: \mathrm{K}$

$$
\begin{aligned}
& =30: 6 \\
& =5
\end{aligned}
$$


Tabel 1

Perhitungan Normalitas Post-test Kelas Eksperimen

\begin{tabular}{|c|c|c|c|c|c|c|}
\hline No & NILAI & X & Fo & fe & $\begin{array}{l}(f o \\
-f e)^{2}\end{array}$ & $x^{2}$ \\
\hline 1 & $\begin{array}{c}95- \\
100\end{array}$ & 97,5 & 2 & 4,16 & 4,66 & 1,120 \\
\hline 2 & $89-94$ & 91,5 & 4 & 4,16 & 0,02 & 0,006 \\
\hline 3 & $83-88$ & 85,5 & 6 & 4,16 & 3,38 & 0,812 \\
\hline 4 & $77-82$ & 79,5 & 8 & 4,16 & 14,7 & 3,533 \\
\hline 5 & $71-76$ & 73,5 & 4 & 4,16 & 0,02 & 0,006 \\
\hline 6 & $65-70$ & 67,5 & 1 & 4,16 & 9,98 & 2,399 \\
\hline \multicolumn{2}{|c|}{ Jumlah } & & 25 & & & $\mathbf{7 , 8 7 6}$ \\
\hline
\end{tabular}

Berdasarkan hasil perhitungan, ditemukan harga Chi-Square hitung=7,876. Harga tersebut selanjutnya dibandingkan dengan Chi-Square tabel, dengan d.b $=6-1=11,1$ pada taraf signifikansi 5\%, maka harga Chi-Square tabel=11,1. Dapat disimpulkan bahwa harga Chi-Square hitung lebih kecil dari harga Chi-Square tabel $(7,876<11,1)$, maka nilai posttest pada kelas eksperimen berdistribusi normal.

Uji homogenitas dengan mencari nilai varian tiap kelas, yaitu kelas kontrol dan kelas eksperimen. Setelah dikelatui nilai varian di masing-masing kelas, selanjutnya yaitu mencari Fmax melalui rumus berikut:

a. $\quad \mathrm{F}_{\max }=\frac{\text { Var.tertinggi }}{\text { Var.terendah }}$

$$
\begin{aligned}
& =\frac{73,1666}{54,6296} \\
& =1,339
\end{aligned}
$$

b. Setelah menghitung Ftabel, langkah selanjutnya yaitu menentukan $\mathrm{db}$ untuk mencari nilai Ftabel :

$\mathrm{Dbx}_{1}=\mathrm{n}-1$

$$
\begin{aligned}
& =25-1 \\
& =24(\mathrm{db} \text { untuk }
\end{aligned}
$$

pembilang)

$$
\begin{aligned}
\operatorname{Dbx}_{2} & =\mathrm{n}-1 \\
& =28-1 \\
& =27 \quad(\mathrm{db} \text { untuk }
\end{aligned}
$$

penyebut)

Setelah menemukan nilai pada Ftabel untuk db 24 dan 27 yaitu 1,93 untuk taraf signifikansi 5\%. langkah selanjutnya kita bandingkan nilai Fmax dan Ftabel, dari perhitungan di atas diketahui nilai Fmax (1,339) < Ftabel $(1,93)$ maka dapat disimpulkan bahwa tidak adanya perbedaan antara nilai pretest kelas kontrol dan kelas eksperimen yang artinya data tersebut bersifat homogen.

Pada kelas kontrol diketahui nilai rata-rata pretest siswa yaitu 67,5 . Sedangkan nilai rata-rata posttest siswa yaitu 69. Sehingga dapat disimpulkan bahwa adanya perbedaan rata-rata pada nilai pretest dan posttest di kelas kontrol. Sedangkan pada kelas eksperimen diketahui nilai rata-rata pretest siswa yaitu 77,6. Sedangkan nilai rata-rata posttest siswa yaitu 83 . Sehingga dapat 
disimpulkan bahwa adanya perbedaan rata-rata pada nilai pretest dan posttest di kelas eksperimen.

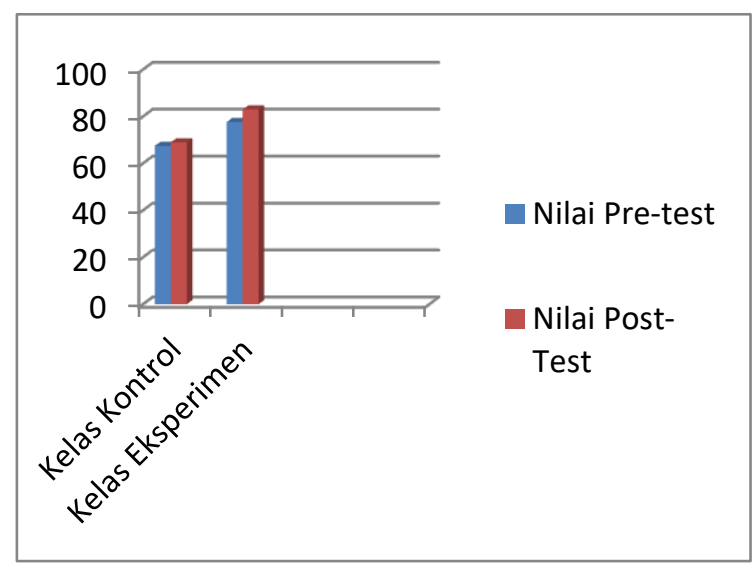

Gambar 1. Perbedaan Rata-rata Nilai Siswa

Berdasarkan hasil data yang diperoleh diketahui bahwa hasil belajar siswa pada pretest dan posttest mengalami peningkatan secara signifikan baik itu nilai siswa di kelas kontrol maupun di kelas eksperimen. Peningkatan nilai rata-rata pretest dan posttest pada kelas eksperimen lebih besar dibandingkan dengan peningkatan nilai rata-rata pada kelas kontrol. Melalui adanya peningkatan nilai ratarata siswa kelas eksperimen yang lebih besar tersebut peneliti menduga bahwa terdapat pengaruh media Ropitri terhadap pembelajaran matematika di kelas eksperimen. Karena proses pembelajaran yang baik akan menghasilkan hasil belajar siswa yang baik juga. Apabila terdapat pengaruh yang lebih baik pada proses pembelajaran matematika melalui penggunaan media Ropitri maka hasil belajar siswa mengalami peningkatan. Untuk mengetahui adanya pengaruh tersebut peneliti menguji hipotesis melalui uji hipotesis pada tahap selanjutnya.

Uji t-test dilakukan untuk menjawab hipotesis penelitian, yaitu ada ataukah tidak ada pengaruh media ropitri media berbasis realistic mathematic education terhadap pembelajaran matematika materi bangun datar siswa kelas III. Berikut hasil hitung dari uji t-test:

Menghitung T-test

$$
\begin{aligned}
& t-\text { test }=\frac{\overline{X_{1}}-\overline{X_{2}}}{\sqrt{\left[\frac{S D_{1}^{2}}{N_{1}-1}\right]+\left[\frac{S D_{2}^{2}}{N_{2}-1}\right]}} \\
& t-\text { est }=\frac{1,607-5}{\sqrt{\left[\frac{10,811}{28-1}\right]+\left[\frac{12}{25-1}\right]}} \\
& t-\text { test }=\frac{-3,393}{\sqrt{0,400+0,5}} \\
& t-\text { test }=\frac{-3,393}{\sqrt{0,9}} \\
& t-\text { test }=\frac{-3,393}{0,948} \\
& t-\text { test }=-3,579
\end{aligned}
$$

Menentukan derajat kebebasan

$$
\begin{aligned}
\mathrm{db} & =N_{x 1}+N_{x 2}-2 \\
& =28+25-2 \\
& =51
\end{aligned}
$$


Dari hasil perhitungan di atas diperoleh nilai $t_{\text {hitung }}$ sebesar $-3,579$. Jika dibandingkan dengan ttabel dengan $\mathrm{db}=51$ pada taraf signifikansi $5 \%$, diperoleh $t_{\text {tabel }}$ sebesar 2,007. Hal ini menunjukkan bahwa $t_{\text {hitung }}$ berada di bawah nilai $t_{\text {tabel }}$ dengan taraf signifikansi 5\%. Jadi hasil yang diperoleh yaitu $-\mathrm{t}$ hitung $(-3,579)<-\mathrm{t}$ tabel $(-2,007)$. Yang berarti bahwa nilai thitung berada pada daerah penolakan $\mathrm{H}_{0}$ atau dengan kata lain $\mathrm{H}_{0}$ ditolak dan Ha diterima. Berdasarkan kaidah pengujian tersebut dapat disimpulkan bahwa terdapat pengaruh yang signifikan dalam penggunaan media ropiri berbasis realistic mathematic education terhadap pembelajaran matematika materi sifat bangun datar siswa kelas III SDN Krembung 1 Sidoarjo. Untuk memperjelas kaidah pengujian tersebut dapat dilihat gambar 4.1 berikut.

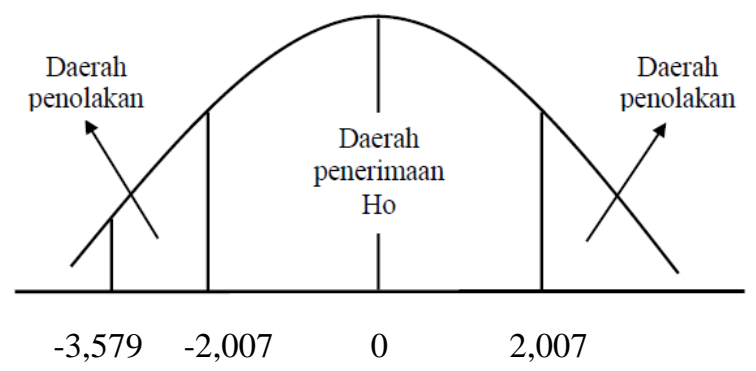

Gambar 2

Daerah Penetuan Ho Pada Uji Komparatif Dua Sample

\section{Pembahasan}

Penelitian dengan jenis Quasi Experiment ini dilaksanakan di SDN Krembung 1 Sidoarjo. Peneliti menggunakan Nonequivalent Control Group Design sehingga dalam penelitian ini terdapat dua kelompok siswa yang terbagi menjadi kelompok siswa kelas kontrol yaitu kelas IIIA dan kelompok siswa kelas eksperimen yaitu kelas IIIB. Teknik pengambilan atau penentuan sampel pada penelitian ini peneliti menggunakan teknik Purposive Sampling sehingga peneliti menentukan untuk kelas eksperimen dan kelas kontrol dalam penelitian ini. Pada pelaksanaan penelitian, peneliti memberikan perlakuan yang berbeda di kelas eksperimen yaitu melakukan pembelajaran dengan menggunakan media Ropitri berbasis Realistic Mathematic Education. Jadi media Ropitri digunakan oleh guru dengan berbasis pendekatan Realistic Mathematic Education. Sedangkan untuk kelas kontrol siswa tidak diberikan perlakuan apapun, dalam arti bahwa pembelajaran bersifat konvensional seperti pembelajaran yang dilakukan sehari-hari. Pembelajaran dilakukan satu kali pertemuan di kelas kontrol dan satu kali pertemuan di kelas eksperimen. 
Sehingga penelitian dilaksanakan selama dua hari. Penelitian ini bertujuan untuk mengetahui ada tidaknya pengaruh dari media Ropitri berbasis pendekatan Realistic Mathematic Education terhadap pembelajaran matematika siswa kelas III. Untuk mengumpulkan data yang akan diolah untuk diketahui ada tidaknya pengaruh dari adanya perlakuan yang berbeda, peneliti menggunakan instrumen penelitian berupa lembar pretest dan lembar posttest.

Penelitian hari pertama dilakukan di kelas kontrol (IIIA) dan yang berperan sebagai guru adalah peneliti. Pembelajaran dimulai pukul 07.00 pagi hari. Setelah guru membuka pembelajaran dan melakukan apersepsi kepada siswa, guru memberikan lembar pretest kepada siswa dan siswa mulai mengerjakan soal pukul 07.10. Guru menyampaikan materi pelajaran dengan memanfaatkan media yang sudah ada di kelas yaitu kertas origami (media pembelajaran konvensional). Buku panduan yang digunakan oleh guru adalah buku BSE Matematika kelas III Kurikulum 2006. Setelah siswa mendapatkan materi, guru memberikan lembar posttest dan siswa mulai mengerjakan soal mulai pukul 07.50. Penelitian hari kedua dilakukan di kelas eksperimen (IIIB) Pembelajaran dimulai pukul 07.00. Setelah guru membuka pembelajaran dan melakukan apersepsi kepada siswa, guru memberikan lembar pretest kepada siswa dan siswa mulai mengerjakan soal pukul 07.10. Guru menyampaikan materi pelajaran dan menggunakan media Ropitri dalam pembelajaran. Pembelajaran di kelas eksperimen berlangsung lebih lama dari pada kelas kontrol. Guru menggunakan model pembelajaran kooperatif dengan menggelompokkan siswa menjadi lima kelompok siswa. Karena jumlah siswa kelas eksperimen adalah dua puluh lima siswa maka terdapat lima kelompok belajar siswa di kelas eksperimen. Guru membagikan media Ropitri dengan ketentuan satu kelompok satu media Ropitri. Begitupun dalam memberikan konteks nyata, guru menggunakan konteks cerita berupa pasar benda yang merupakan tempat dimana terdapat contoh-contoh benda bangun datar dalam kehidupan. Terdapat lima pasar benda dalam kelas dan satu kelompok siswa mengidentifikasi benda-benda pada satu pasar benda.

Dalam penggunaaan media Ropitri guru menggunakan pendekatan Realistic Mathematic Education. Siswa mengidentifikasi benda-benda bangun 
datar dan menemukan sifat-sifat bangun secara mandiri. Namun dalam Realistic Mathematic Education terdapat tahap "guided reinvention" yang berarti suatu proses menemukan kembali konsep matematika dengan bimbingan orang dewasa. Pada tahap inilah media Ropitri berperan banyak dalam proses pembelajaran matematika materi sifat bangun datar sederhana siswa kelas III. Siswa dapat melakukan crosschecking jawaban dari kegiatan identifikasi secara mandiri mereka dengan jawaban yang terdapat pada media Ropitri. Namun kegiatan crosscheck secara mandiri oleh siswa bukan berarti menghapus tugas guru. Penggunaan media Ropitri dilakukan bersama-sama dengan bimbingan seorang guru.

Penggunaan media Ropitri yang dilakukan dengan pendekatan realistik diharapkan dapat menambah semangat belajar siswa dan siswa senang untuk belajar matematika, sehingga pembelajaran tersebut bermakna bagi kehidupan siswa. Pada penelitian ini terlihat pada kondisi pembelajaran dalam kelas eksperimen yang lebih menarik dan menyenangkan. Dengan kondisi tersebut siswa dapat belajar dengan nyaman dan memperoleh hasil belajar yang lebih baik. Hal ini dapat diketahui dari perolehan hasil belajar siswa kelas eksperimen yang mengalami peningkatan cukup besar dibanding kelas kontrol. Pada kelas kontrol berubah hasil belajar siswa yang mengalami peningkatan dari rata-rata nilai pretest 67,5 menjadi rata-rata nilai posttest 69,1 sedangkan pada kelas eksperimen peningkatan rata-rata nilai siswa lebih besar yaitu dari rata-rata nilai pretest sebesar 77,6 menjadi rata-rata nilai posttest 83. Untuk memastikan adanya perubahan yang signifikan tersebut peneliti melakukan uji t-test atau uji hipotesis untuk mengetahui apakah memang terdapat pengaruh ataukah tidak. Sebelum melakukan uji t-test peneliti juga melakukan uji normalitas dan homogenitas.

Pada uji normalitas peneliti menggunakan rumus chi-square, dengan harga Chi-Square hitung sebesar 7,876 dan 2,601. Kedua skor tersebut berada di bawah nilai chi-square tabel yang menunjukkan skor 35,4 untuk db 5 pada taraf signifikan 5\% yang berarti data kedua kelas berdistribusi normal. Selanjutnya yaitu uji homogenitas dengan nilai pada $\mathrm{F}_{\text {tabel }}$ untuk db 24 dan 27 yaitu 1,93 untuk taraf signifikansi $5 \%$. Perhitungan nilai Fmax yang diperoleh adalah Fmax $(1,339)<$ Ftabel $(1,93)$ maka dapat disimpulkan bahwa tidak 
adanya perbedaan antara nilai pretest kelas kontrol dan kelas eksperimen yang artinya data tersebut bersifat homogen. Terakhir peneliti melakukan uji t-test untuk menguji hipotesis penelitian ini mengenai ada tidaknya pengaruh media Ropitri yang digunakan dengan berbasis pendekatan Realistic Mathematic Education. Hasil yang diperoleh dari uji t-test yaitu nilai $t_{\text {hitung }}$ sebesar $-3,579$, dengan ttabel $\mathrm{db}=51$ pada taraf signifikansi $5 \%$, diperoleh $t_{\text {tabel }}$ sebesar 2,007. Hal ini menunjukkan bahwa $t_{\text {hitung }}$ berada di bawah nilai $t_{\text {tabel }}$ dengan taraf signifikansi 5\%. Jadi hasil yang diperoleh yaitu $-\mathrm{t}$ hitung $(-3,579)<-\mathrm{t}$ tabel (-2,007). Melalui data tersebut maka hipotesis telah terjawab, dengan diketahuinya nilai $t_{\text {hitung }}$ berada pada daerah penolakan $\mathrm{H}_{0}$ atau dengan kata lain $\mathrm{H}_{0}$ ditolak dan $\mathrm{Ha}$ diterima. Jadi peneliti menyimpulkan bahwa terdapat pengaruh yang signifikan dalam penggunaan media ropiri berbasis Realistic Mathematic Education terhadap pembelajaran matematika materi sifat bangun datar siswa kelas III SDN Krembung 1 Sidoarjo.

\section{KESIMPULAN}

Berdasarkan pembahasan analisis data penelitian tentang pengaruh media
Ropitri berbasis Realistic Mathematic Education, maka dapat disimpulkan bahwa pembelajaran dengan menggunakan media Ropitri memiliki pengaruh yang signifikan terhadap pembelajaran matematika materi sifat bangun datar pada siswa kelas III. Hal tersebut diketahui dari hasil yang diperoleh dari uji t-test yaitu nilai $t_{\text {hitung }}$ sebesar $-3,579$, dengan ttabel $d b=51$ pada taraf signifikansi $5 \%$, diperoleh $\mathrm{t}_{\text {tabel }}$ sebesar 2,007. Hal ini menunjukkan bahwa $t_{\text {hitung }}$ berada di bawah nilai $t_{\text {tabel }}$ dengan taraf signifikansi 5\%. Jadi hasil yang diperoleh yaitu $-t$ hitung $(-3,579)<-$ $\mathrm{t}$ tabel $(-2,007)$. Hipotesis penelitian telah terjawab dengan diketahuinya nilai $t_{\text {hitung }}$ berada pada daerah penolakan $\mathrm{H}_{0}$ atau dengan kata lain $\mathrm{H}_{0}$ ditolak dan $\mathrm{Ha}$ diterima.

\section{DAFTAR PUSTAKA}

Alan, Riedesel. 1996. Teaching Elementary School Mathematics. United States of America: Library of Congress Catalouging

Arikunto, Suharsimi 2010. Prosedur Penelitian Suatu Pendekatan Praktik. Jakarta: Rineka Cipta

Arsyad, Azhar. 2014. Media Pembelajaran. Jakarta: Rajawali Press

Baharuddin dan Wahyuni. 2015. Teori Belajar dan Pembelajaran. Yogyakarta: Ar-Ruzz Media 
Budiningsih, Asri. 2005. Belajar dan Pembelajaran. Jakarta: PT. Rineka Cipta

Budiyono. 2016. Geometri dan Pengukuran. Yogyakarta: Ombak

Dahar, Ratna. 2011. Teori-Teori Belajar dan Pembelajaran. Jakarta: Erlangga

Fathurrohman, Muhammad. 2015. Model-Model Pembelajaran Inovatif. Yogyakarta: Ar-Ruzz Media

Hadi, Sutarto. 2005. Pendidikan Matematika Realistik dan Implementasinya. Banjarmasin: Tulip

Heruman. 2014. Model Pembelajaran Matematika di Sekolah Dasar. Bandung: PT. Remaja Rosdakarya

Pitadjeng. 2015. Pembelajaran Matematika yang Menyenangkan. Yogyakarta: Graha Ilmu

Purnomo, Yoppy. 2015. Pembelajaran Matematika untuk PGSD. Jakarta: Erlangga

Rajagukguk, Waminton. 2015. Evaluasi Hasil Belajar Matematika. Yogyakarta: Media Akademi 